\title{
Role of snow and glacier melt in controlling river hydrology in Liddar watershed (western Himalaya) under current and future climate
}

\author{
G. Jeelani, ${ }^{1}$ Johannes J. Feddema, ${ }^{2}$ Cornelis J. van der Veen, ${ }^{2}$ and Leigh Stearns ${ }^{3}$ \\ Received 9 November 2011; revised 1 October 2012; accepted 14 October 2012; published 12 December 2012.
}

[1] Snowmelt and icemelt are believed to be important regulators of seasonal discharge of Himalayan rivers. To analyze the long term contribution of snowmelt and glacier/icemelt to river hydrology we apply a water budget model to simulate hydrology of the Liddar watershed in the western Himalaya, India for the 20th century (1901-2010) and future IPCC A1B climate change scenario. Long term (1901-2010) temperature and precipitation data in this region show a warming trend $\left(0.08^{\circ} \mathrm{C} \mathrm{yr}^{-1}\right)$ and an increase in precipitation $(0.28 \mathrm{~mm}$ $\mathrm{yr}^{-1}$ ), with a significant variability in seasonal trends. In particular, winter months have undergone the most warming, along with a decrease in precipitation rates; precipitation has increased throughout the spring. These trends have accelerated the melting and rapid disappearance of snow, causing a seasonal redistribution in the availability of water. Our model results show that about $60 \%$ of the annual runoff of the Liddar watershed is contributed from the snowmelt, while only $2 \%$ is contributed from glacier ice. The climate trend observed from the 1901 to 2010 time period and its impact on the availability of water will become significantly worse under the IPCC climate change scenarios. Our results suggest that there is a significant shift in the timing and quantity of water runoff in this region of the Himalayas due to snow distribution and melt. With greatly increased spring runoff and its reductions in summer potentially leading to reduced water availability for irrigation agriculture in summer.

Citation: Jeelani, G., J. J. Feddema, C. J. van der Veen, and L. Stearns (2012), Role of snow and glacier melt in controlling river hydrology in Liddar watershed (western Himalaya) under current and future climate, Water Resour. Res., 48, W12508, doi:10.1029/ 2011WR011590.

\section{Introduction}

[2] Himalayan rivers are a key source of fresh water to more than one billion people [Ives and Messerli, 1989]. They support one of the most heavily irrigated regions in the world in northern India [Tiwari et al., 2009], while the Pakistan economy is largely dependent on water resources originating in the upper Indus for agricultural irrigation and hydropower generation [Karim and Veizer, 2002; Archer et al., 2010]. Quantitative estimates of the spatial and temporal distribution of the upstream water sources that feed these systems are essential, yet remain a challenge for policy makers and managers that operate in downstream regions.

\footnotetext{
${ }^{1}$ Department of Geology and Geophysics, University of Kashmir, Hazratbal Srinagar, India.

${ }^{2}$ Department of Geography, University of Kansas, Lawrence, Kansas, USA.

${ }^{3}$ Department of Geology, University of Kansas, Lawrence, Kansas, USA.

Corresponding author: G. Jeelani, Department of Geology and Geophysics, University of Kashmir, Hazratbal Srinagar, India. (geojeelani@ gmail.com)

C2012. American Geophysical Union. All Rights Reserved. 0043-1397/12/2011WR011590
}

[3] A quantitative assessment of the contribution from snow and glacier melt to river systems is not generally available for the Himalayas, and is sometimes misrepresented in the literature as glacial contribution only [e.g., Barnet et al., 2005] or snowmelt only [Bookhagen and Burbank, 2010]. These estimates are difficult to obtain because of the remoteness of the watersheds and lack of instrumentation. Published estimates of glacial and/or snowmelt contribution to the regional hydrology either vary greatly or are qualitative in nature and are typically for very short periods of observation (Table 1). To accurately monitor current water resources and predict how these resources may be affected by climate change, improved knowledge of river hydrology is needed. In particular, the runoff lag due to the seasonal snowpack and glaciers in the upper Himalayan basins may determine the timing of the irrigation water for agriculture during the high demand summer crop season and for hydropower generation.

[4] In regions where the water supply is currently dominated by melting snow or ice, the increase in surface temperatures may have important consequences for the hydrological cycle. Projections of future water resource for the region have suggested that the region is likely to run out of water during the dry season if the current warming and glacial melting trends continue for several more decades [Barnett 
Table 1. Some of the Estimates of Various Components of River Flow in Himalayas

\begin{tabular}{|c|c|c|c|c|c|}
\hline \multirow[b]{2}{*}{ Basin Name } & \multicolumn{4}{|c|}{ Contribution (\%) From } & \multirow[b]{2}{*}{ Reference } \\
\hline & Snow and Ice & Snow & Glacier & Rainfall & \\
\hline \multirow[t]{2}{*}{ Upper Indus } & 72 & 40 & 32 & - & Immerzeel et al. [2009] \\
\hline & $>80$ & - & - & - & Archer and Fowler [2004] \\
\hline Indus & - & $<50$ & - & $>50$ & Bookhagen and Burbank [2010] \\
\hline Eastern Himalayas (Ganges) & - & $<20$ & - & $>80$ & Bookhagen and Burbank [2010] \\
\hline Brahamputra & - & 34 & - & - & Bookhagen and Burbank $[2010$ \\
\hline Chenab (Indus) & 49 & - & - & 50.9 & Singh et al. [1997] \\
\hline Satluj (Indus) & 59 & - & - & 41 & Singh and Jain [2002] \\
\hline Ganges (Nepal Himalayas) & - & - & 4 & - & Alford and Armstrong [2010] \\
\hline Liddar (Indus) & 62 & 60 & 2 & - & Present Study \\
\hline
\end{tabular}

et al., 2005], and that, should Himalayan glaciers continue to retreat rapidly, water shortages might be widespread within a few decades [Rees and Collins, 2006]. Barnett et al., [2005] suggested that the reduction in snowpack and the melting of winter snow is already occurring earlier each spring in the Indus basin. Over the last century, the Indus basin exhibits a stronger warming trend than the northern hemisphere average for every season [Immerzeel et al., 2009]. Some studies have suggested a decrease of river flow in the Indus due to climate change [Rees and Collins, 2006; Briscoe and Qamar, 2007; Akhtar et al., 2008; Immerzeel et al., 2009]. Several studies suggest that significant glacial retreat across the HimalayaKarakuram-Hindukush is causing a reduction in river flow [Berthier, 2007; Eriksson et al., 2009; Bookhagen and Burbank, 2010]. However, the effects of climate change on glaciers and river flow in Himalaya-Karakuram-Hindukush is still not clear [Archer et al., 2010; Immerzeel et al., 2010; Bolch et al., 2012].

[5] Such projections and assumptions may be questioned in the absence of a quantitative assessment of the current availability of water resources and a quantitative assessment of future outcomes. Hence there is a need to understand and estimate the relative contribution of runoff from glacier ice, snow, and rainfall to these river systems, and determine how these relationships may change under climate change conditions. Water balance models have been shown to be effective at simulating generic hydrology characteristics of river systems at local scales [Thornthwaite, 1948; Thornthwaite and Mather, 1955; Mather, 1978] as well as at continental and global scales [Feddema, 1998; Willmott et al., 1985a; McCabe and Wolock, 1999]. Two advantages of this type of model is that it addresses the relative runoff contributions from rain, snow, and ice across a watershed and that it is amenable to longer time periods of analyses compared to satellite based observations. This study aims to estimate the relative contribution of snowmelt and icemelt to the total runoff, and changes in runoff timing and quantity for a tributary basin to the Indus River over the past century and for future climate projections. In addition, we compare how river discharge compares to agriculture water need in Kashmir Valley under present conditions and future climate projections.

\section{Study Area}

[6] This study focuses on the Liddar watershed in the upper Jhelum basin, a tributary of the Indus river system, located in the western Himalaya between latitudes $33^{\circ} 59^{\prime}$ and $34^{\circ} 12^{\prime}$ and longitudes $75^{\circ} 09^{\prime}$ and $75^{\circ} 23^{\prime}$ (Figure 1), and covering an area of $653 \mathrm{~km}^{2}$. The altitude of the watershed ranges from 2050 to $\sim 5200 \mathrm{~m}$ above mean sea level. As per the IPCC [2007] report the area lies in TIB. The watershed is one of a few catchments within the Jhelum basin with permanent snow, and permanent ice/glaciers occupy about $3 \%$ of the entire Liddar watershed and $6 \%$ of the upper Liddar watershed area. The Liddar watershed has 17 glaciers [Kaul, 1990] which cover an area of about about $40 \mathrm{~km}^{2}$ in 2008 . Kolahoi and Shishram are the major glaciers with an area of about $\sim 10.2$ and $\sim 8.5 \mathrm{~km}^{2}$, respectively. Most of the other glaciers are very small (less than $1 \mathrm{~km}^{2}$ ). These satellite measurements of areal extent of the glaciers are typically overestimated/underestimated by the debris cover and the seasonal snow. The total debris cover in Himalaya-Karakuram is about $10 \%$ [Bolch et al., 2012], which not only retards the surface melting but also reduces the glacier flow velocities particularly in glacier tongues [Scherler et al., 2011]. The hypsometry of the watershed and the glaciers (Figure 2) shows that maximum area of the entire watershed and the glaciers lie between 3500 and $4500 \mathrm{~m}$ amsl, and 4300 and $4500 \mathrm{~m}$ amsl, respectively.

[7] The region experiences four distinct seasons: winter (December to February), spring (March to May), summer (June to August), and autumn (September to November) and has a temperate climate with average annual precipitation of $\sim 1200 \mathrm{~mm}$ at Pahalgam station (2130 m altitude). Like other parts of the Jhelum basin, the streamflow of the Liddar watershed originates from seasonal snowmelt/icemelt and rainfall. The weather in the western Himalaya has a marked seasonality in temperature and precipitation, which is dominated by midlatitude frontal disturbances. These disturbances are most active during winter and spring and decrease substantially as summer progresses [Jeelani et al., 2010]. Most of the Indus basin (90\%) is not affected by summer monsoon systems [Immerzeel et al., 2009].

[8] In the upper catchments $(>2000 \mathrm{~m})$ of the western Himalayas, precipitation generally falls as snow from late autumn to early spring. Redistribution of snow by wind and slopes is commonly observed in the Himalayas. Some of the snow tends to be deposited along the valleys, which, depending upon their orientation, normally remain under shade, particularly in E-W oriented valleys. These sites are therefore the reservoirs for the river flow for the rest of the year. The snow cover area in the Liddar watershed, although highly variable, decreases from about $90 \%$ in winter (January) to about $6 \%$ in autumn (September). 


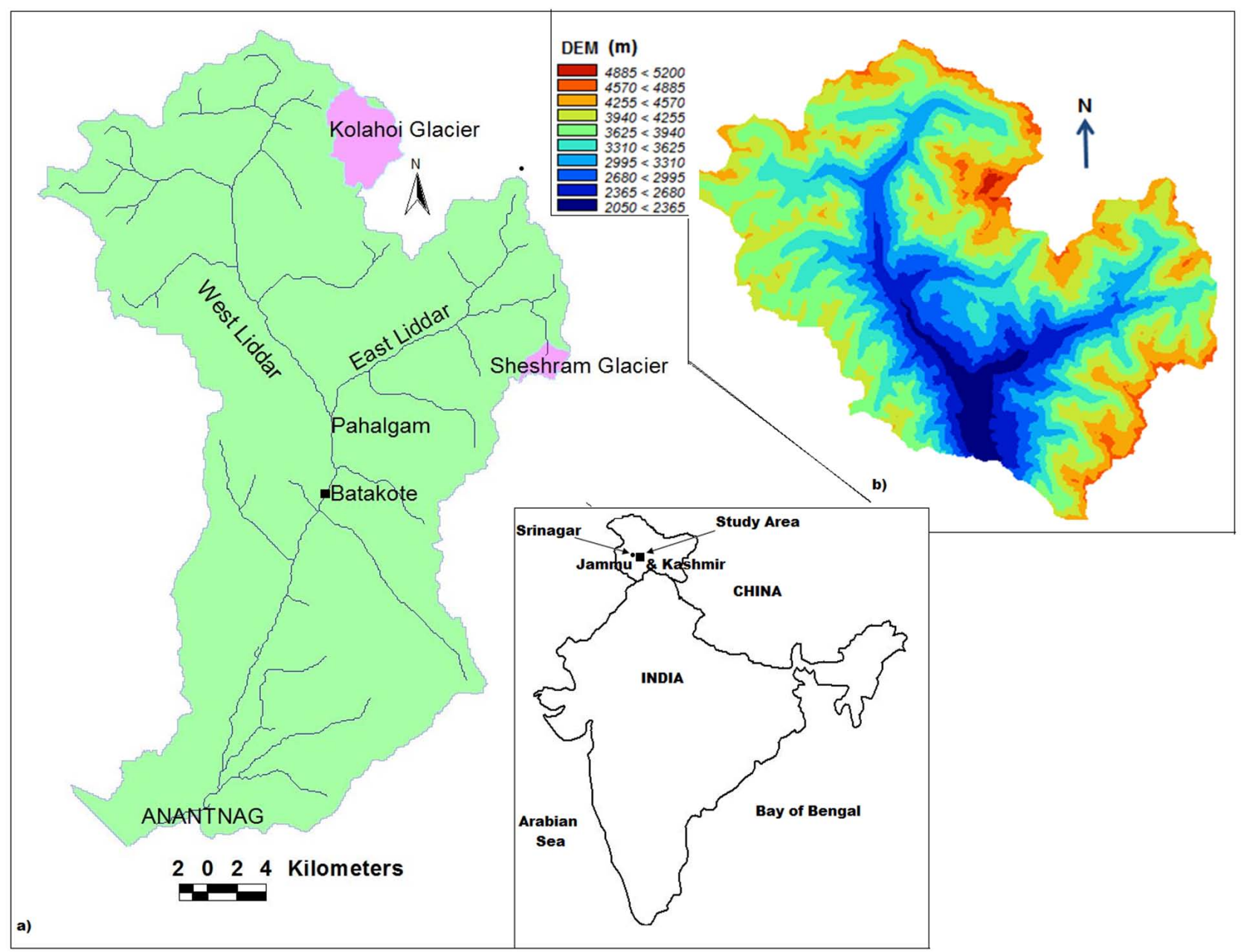

Figure 1. Location map of the study area showing (a) Liddar watershed and (b) DEM (digital elevation model) of the upper Liddar watershed in masl, derived from SRTM.

\section{Methodology}

\subsection{Model Description}

[9] Given the scarcity of climate and terrain classification information for the region, any attempt to simulate the general hydrology of these remote watersheds needs to draw on models with minimal input requirements and adjustments. This study uses a watershed model derived from the global scale water balance models used by Willmott et al. [1985b], McCabe and Wolock [1999], and Feddema [2005]. Aspects of these models have been combined and modified to simulate watershed runoff and hydrology for different elevation zones in the study region. The model partitions monthly precipitation totals into snowfall when the monthly average temperature is below freezing. Snowmelt is estimated based on the average monthly temperature and average daily precipitation values using the daily snowmelt function from Willmott et al. [1985b] and is adjusted for the number of days in the month. Total rainfall and snowmelt are then partitioned into overland runoff and effective precipitation (infiltrated into the soil column). The rate of overland runoff is based on the projected monthly soil water content and monthly water need as follows:

$$
f R O=f R O_{\min }+\left(f R O_{\max }-f R O_{\min }\right) \begin{cases}P+M<=W H C-S T, & 0 \\ (W H C-S T)<P+M<(2 W H C-S T+P E), & (P+M-W H C+S T) /(W H C+P E) \\ P+M>2 W H C-S T+P E, & 1 .\end{cases}
$$



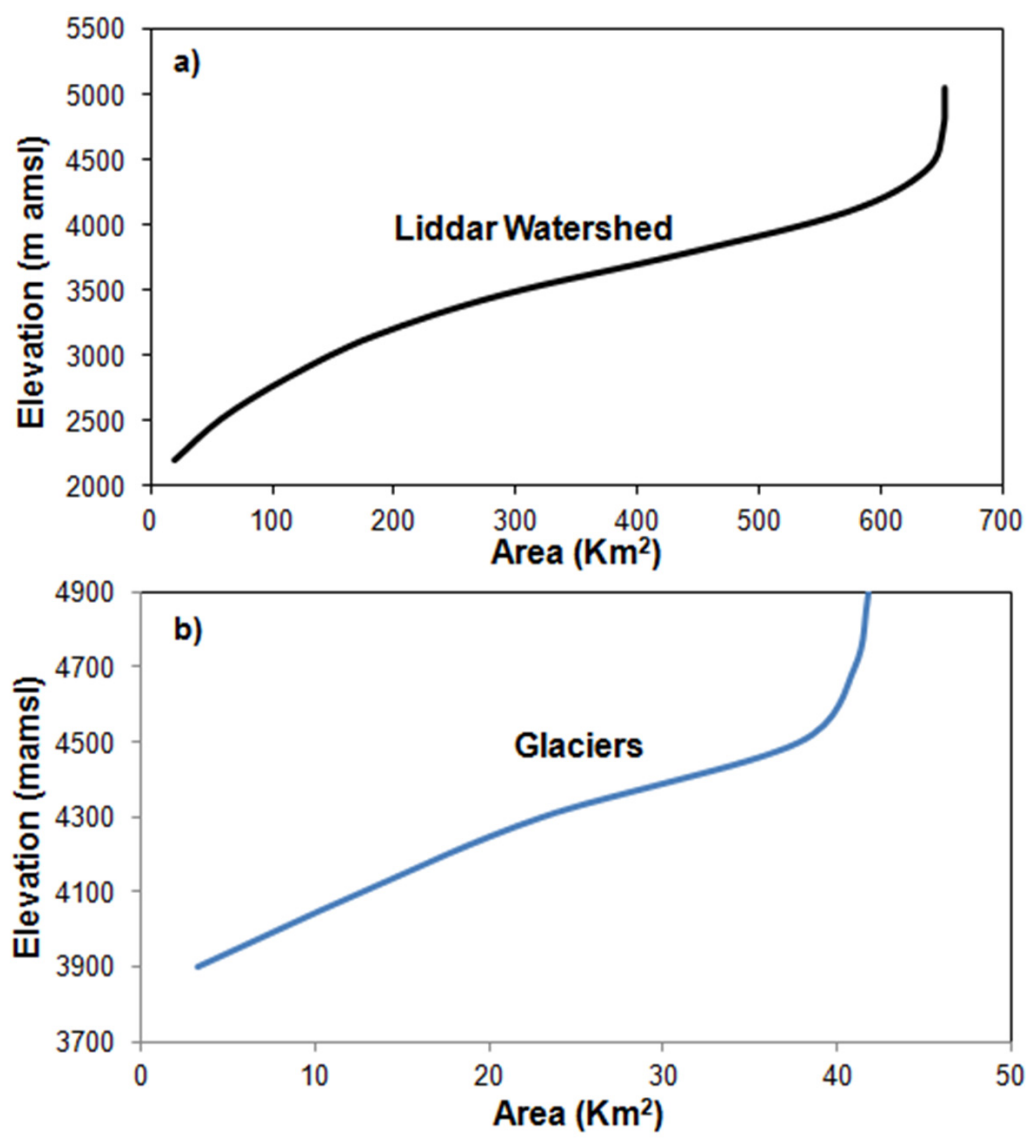

Figure 2. Hypsometry of the Liddar watershed and the glaciers.

Where $f R O$ is the fraction of monthly precipitation $(P)$ and melt water $(M)$ that becomes overland runoff, and $f R O_{\text {min }}$ and $f R O_{\max }$ are the minimum and maximum threshold fractions assigned for the zone (see Table 2), water holding capacity $(W H C)$ is the ability of soil or compost to retain moisture against drainage due to gravity, $P E$ is potential evapotranspiration, and $S T$ is the amount of water in soil storage at the end of the previous month.

[10] Water demand or potential evapotranspiration (PET) for each elevation zone is estimated by the Hamon method after McCabe and Wolock [1999], who evaluated snow pack influence on U.S. watersheds [see also Hamon,

Table 2. Model Parameter Settings ${ }^{\mathrm{a}}$

\begin{tabular}{|c|c|c|c|c|c|c|c|c|c|}
\hline \multirow[b]{2}{*}{ Zone } & \multirow[b]{2}{*}{ Area $\left(\mathrm{km}^{2}\right)$} & \multicolumn{2}{|c|}{ Elevation (m) } & \multirow[b]{2}{*}{$\mathrm{WHC}^{\mathrm{b}}(\%)$} & \multicolumn{2}{|c|}{$\begin{array}{l}\text { Overland } \\
\text { Flow (\%) }\end{array}$} & \multirow[b]{2}{*}{ Lag (\%) } & \multirow{2}{*}{$\begin{array}{c}\text { Snow } \\
\text { Lag }(\%)\end{array}$} & \multirow{2}{*}{$\begin{array}{c}\text { Water } \\
\text { Loss }(\%)\end{array}$} \\
\hline & & Min & Max & & Min & Max & & & \\
\hline 1 & 20.4 & 2050 & 2365 & 60 & 0.05 & 0.4 & 63 & 10 & 10 \\
\hline 2 & 38.3 & 2365 & 2680 & 54 & 0.1 & 0.45 & 60 & 11 & 10 \\
\hline 3 & 54.9 & 2680 & 2995 & 49 & 0.15 & 0.5 & 57 & 11 & 9 \\
\hline 4 & 70.4 & 2995 & 3310 & 44 & 0.2 & 0.55 & 54 & 12 & 9 \\
\hline 6 & 149.2 & 3625 & 3940 & 35 & 0.3 & 0.65 & 49 & 13 & 8 \\
\hline 7 & 129.6 & 3940 & 4255 & 32 & 0.35 & 0.7 & 47 & 13 & 7 \\
\hline 8 & 59.5 & 4255 & 4570 & 29 & 0.4 & 0.75 & 44 & 14 & 7 \\
\hline 9 & 12.5 & 4570 & 4885 & 26 & 0.45 & 0.8 & 42 & 14 & 6 \\
\hline 10 & 1.1 & 4885 & 5200 & 23 & 0.5 & 0.85 & 40 & 15 & 6 \\
\hline 11 & 1.6 & 3800 & 4000 & 5 & 0.1 & 0.5 & 10 & 16 & 5 \\
\hline 12 & 2.6 & 4000 & 4200 & 5 & 0.13 & 0.53 & 10 & 17 & 5 \\
\hline 13 & 2.6 & 4200 & 4400 & 5 & 0.15 & 0.55 & 10 & 18 & 5 \\
\hline 15 & 0.8 & 4600 & 4800 & 5 & 0.2 & 0.6 & 10 & 20 & 5 \\
\hline 16 & 0.3 & 4800 & 5000 & 5 & 0.23 & 0.63 & 10 & 21 & 5 \\
\hline
\end{tabular}

${ }^{\text {a } Z o n e s ~} 1$ to 10 are without ice and zones 11 to 16 represent glacier covered areas.

${ }^{\mathrm{b}}$ Water holding capacity. 
1963; Lu et al., 2005]. The procedure for determining soil moisture withdrawal and actual evapotranspiration is modified to be dependent on the monthly water demand and on the quantity of water held in the soil as follows:

$$
\Delta S M_{m}=\left(P_{m}-P E T_{m}\right) \times\left(0.64^{(P-P E T) / W H C}\right) \times S M_{m-1} / W H C,
$$

where $\Delta S M_{m}$ represents the amount of water withdrawn from the soil $(\triangle S M)$ in the current month (subscript $m$ ), $\left(P_{m}-P E T_{m}\right)$ represents the difference between precipitation input and PET for the current month, $0.64^{(P-P E T) / W H C}$ represents how much water extraction is reduced because water is more difficult to extract as it is withdrawn over the period of the month, and the final term represents a scaling factor based on soil water content at the beginning of the month. Surplus moisture, calculated as excess moisture in the soil (above WHC), is partitioned into recharge (percolation to groundwater and other water losses) and to throughflow that returns to the surface. Base flow from the area is estimated based on up to six month lags of throughflow values, and total river flow is estimated from base flow and the present month's overland flow. Specific parameter settings for each elevation zone are shown in Table 2.

[11] Over glacier areas, which may overlap in elevation with nonglaciated portions of the watershed at the same or higher elevation, a similar water balance is calculated, but with some modifications. In this case it is assumed there is a total WHC of $5 \mathrm{~mm}$, and snow accumulates on the ice during freezing conditions. Above freezing, snow melts as described for soil areas, and once all the snow has melted, ice will melt. Ice is assumed to melt at half the rate of snowmelt, based on estimates of melt rates for snow and ice by Hock [2003]. Over long time periods there are instances where snow will not melt away every season and accumulates over time. This snow is assumed to remain as snow throughout the time period of study. By comparing snow depth through time, it is possible to assess the equilibrium line altitude (ELA) of the glaciers (snow will accumulate above the equilibrium line and melt below that elevation). 1:50,000 scale Geological Survey India toposheets (1964) and $90 \mathrm{~m}$ resolution Aster image (2007) were used to assess the overall retreat of the Kolahoi Glacier (major glacier of the study area). The annual glacier shrinkage for Kolahoi Glacier was estimated to be about $0.04 \mathrm{~km}^{2} \mathrm{yr}^{-1}\left(0.34 \% \mathrm{yr}^{-1}\right)$ during the period 1964 to 2008 . We have applied the same retreat rate to whole glacier cover in the model from 1964 by assuming that all the glaciers respond similarly to climate.

[12] In addition to climate data, a number of input variables are needed to describe the landscape characteristics to the water balance model (Table 2). These include: zonal elevation; estimates of water holding capacity (WHC); estimates of lower and upper bounds of rainfall percentage lost to overland flow; and estimates of the lag time for these flows to the river. Because of significant shading in this mountainous region, not all snow will be exposed to equal melt rates, hence an additional lag is introduced to allow for a portion of snow pack to be retained into the next month (snow lag), unless snow pack is less than $100 \mathrm{~mm}$ water equivalent, in which case all the snow can be melted away. Finally, in this highly fractured and steep mountain area, there is significant
Table 3. Multimodel IPCC Scenarios of the 25th, 50th, and 75th Percentile Estimates for the Tibetan Plateau Region (TIB) Temperature and Precipitation Scenarios ${ }^{\mathrm{a}}$

\begin{tabular}{cccccccccc}
\hline & & \multicolumn{2}{c}{$\begin{array}{c}\text { Temperature } \\
\text { Response (\%) }\end{array}$} & & & \multicolumn{2}{c}{$\begin{array}{c}\text { Precipitation } \\
\text { Response (\%) }\end{array}$} \\
\cline { 3 - 5 } \cline { 7 - 9 } Region & Season & 25 & 50 & 75 & & 25 & 50 & 75 \\
\hline TIB 30N,50E & DJF & 3.7 & 4.1 & 4.9 & & 12 & 19 & 26 \\
to 75N,100E & MAM & 2.9 & 3.6 & 4.3 & & 4 & 10 & 14 \\
& JJA & 3.2 & 4.0 & 4.7 & & 0 & 4 & 10 \\
& SON & 3.3 & 3.8 & 4.6 & & -4 & 8 & 14 \\
\hline
\end{tabular}

${ }^{\text {a }}$ Source: IPCC [2007, Table 11.1].

water loss to the atmosphere from temporary storage areas (lakes) and loss to infiltration of water to the subsurface where some of it may be lost to interbasin water transfer and subsurface flows out of the watershed.

[13] This model is intended for use in a wide range of high elevation watersheds. For this study the Liddar watershed was divided into 16 altitude zones: ten $310 \mathrm{~m}$ elevation zones without glacier areas and six $200 \mathrm{~m}$ elevation zones specifically to simulate glacier areas only. Water budgets were run for each zone (represented as separate sheets in an Excel program in the auxiliary material). ${ }^{1}$ Water balance and runoff estimates for each zone were then aggregated based on area and runoff quantities were estimated for the mouth of the watershed at the Batakote stream gauge (latitude: N $33^{\circ} 56^{\prime} 59.26^{\prime \prime}$ longitude: E $75^{\circ}$ $18^{\prime} 12.11^{\prime \prime}$ altitude: $2050 \mathrm{~m}$ ).

[14] The hydrological response of the Liddar watershed to climate change is assessed based on the IPCC regional climate change scenarios (Table 3) projected for the years 2080-2099, with 1980-1999 as present day reference period [IPCC, 2007]. The changes in temperature and precipitation were applied as absolute amounts for temperature and as percentage changes of the observed monthly values from 1901 to 2010 for three different ( $25 \%, 50 \%$, and $75 \%$ quartile) scenarios. Both temperature and precipitation were increased linearly over the record 1901-2010 assuming zero change in 1890 (representing 1990) to the projected IPCC 2100 values by 1990 (representing 2090). Because there is no data prior to 1900 , the observations reflect a $10 \%$ IPCC change starting in January 1900; values that are close to present day conditions (i.e., 2000) given observed climate changes over the last century. By applying progressive changes through 1990 in the observed record, we simulate 2090 conditions; with the period 2090-2110 representing end of 21st century conditions (i.e., monthly 1990-2010 values plus the constant IPCC 2100 values applied). This methodology does not account for projected changes in the frequency of weather events, and inherits observed variability from the 20th century in addition to the IPCC projected changes. While this methodology is limited and presents only one potential outcome of a future climate scenario it is straight forward and, because the model uses monthly time steps, precise weather event projections are less critical compared to methods that use daily time steps to simulate climate change.

\footnotetext{
${ }^{1}$ Auxiliary material data sets are available at $\mathrm{ftp}: / / \mathrm{ftp}$. agu.org/apend/wr/ 2011 wr011590.
} 
[15] To assess the total water demand for the agriculture in the region, moisture deficit conditions (potential evapotranspiration - actual evapotranspiration) is multiplied by the agricultural area in the Kashmir valley $\left(1514 \mathrm{~km}^{2}\right)$ which comprises about $11.8 \%$ of the Jhelum basin $\left(12760 \mathrm{~km}^{2} \mathrm{In}-\right.$ dian controlled; http://diragrikmr.nic.in/ [Raina 2002]). The upper Jhelum catchment comprises $5.4 \%$ of the total area of Kashmir valley, and it is one of a few major catchments supplying summer water to the agricultural area. Thus, the Jhelum water supply (summed runoff from June through September) can be directly compared to the water need of the agricultural area using the estimated monthly water deficit conditions at Srinagar station (summed from June through September multiplied by the area in agriculture).

\subsection{Data}

[16] Several climate data sources have been used for this analysis. Monthly temperature and precipitation records were obtained from the Indian Meteorological Department (IMD), and the Royal Netherlands Meteorological Institute (KNMI) Climate Explorer website (http://climexp.knmi.nl/). Stream discharge data for the Batakote gauge from January 1990 to December 2000 were obtained from the Floods (P\&D) Division, Kashmir Irrigation and Flood Control Department, Government of Jammu and Kashmir. All the data related to temperature, precipitation, and stream discharge used in this paper is observation based collected by the expert staff of IMD and P\&D.

[17] The Shuttle Radar Topographic Mission (SRTM) Version 2 with a $90 \mathrm{~m}$ grid cell size topographic data (http:// srtm.csi.cgiar.org/SRT-ZIP/SRTM_Data_GeoTiff) was used to derive topographic variables to delineate various elevation zones and to estimate the area of these zones and the entire watershed. SAGA (free open source software) was used for SRTM interpretation. The aster image was available free of cost from the website http://glcfapp.glcf.umd.edu/.

\subsection{Temperature Lapse Rate and Precipitation Gradient}

[18] To estimate temperate and precipitation inputs for each elevation zone monthly temperature lapse rate and precipitation gradients were calculated by choosing the weather stations at different elevations with at least 10 overlapping observational years: 1968-1977 for temperature and 1961-1970 for precipitation (Table 4). Temperature gradients show a very good correlation $\left(r^{2}>0.7\right)$ across all weather stations of the Indus basin. This is in agreement with the positive correlation of the seasonal temperatures across the upper Indus basin found by Fowler and Archer [2006]. However, due to the high spatial and temporal variability in precipitation, only local stations from Kashmir Valley (not whole Indus) were used for precipitation gradients. Positive correlation $\left(r^{2}>0.8\right)$ was found from January to May, and the worst correlations $\left(r^{2}>0.1\right)$ were found in July and August; because local scale convective systems in the summer have less correlation compared to large scale frontal systems in winter. However, because summer precipitation is low in the region and because it has negligible influence on glacier growth, these low summer correlations should be of little consequence to our study outcomes. These results support finding by Archer and Fowler [2004] who found positive correlations across stations of the upper Indus in winter only. The data from $12(1968-1977)$ and 6 (1961-1970) weather stations (Table 4) was used to estimate monthly temperature lapse rate and precipitation gradients, respectively (Table 5). These lapse rates were then applied to the Srinagar base station data to estimate monthly temperature and precipitation values for each elevation zone (Table $6)$.

\subsection{Model Validation}

[19] Model validation is based on estimates of monthly average river flows at the Batakote stream gauge at the base of the watershed. However, the station only has sporadic observations, typically two to six measurements per month at different times of the day, which does not provide a very reliable measure of observed monthly flow rates. Because of this, we recognize that the validation is problematic, and we stress the great need for improved weather and water resource data collection to improve future model development and to be able to improve parameter estimation. The daily variation of runoff (Figure 3 ) is dependent

Table 4. Name and Coordinates of the Weather Stations Used for the Analysis (1- KNMI and 2- IMD)

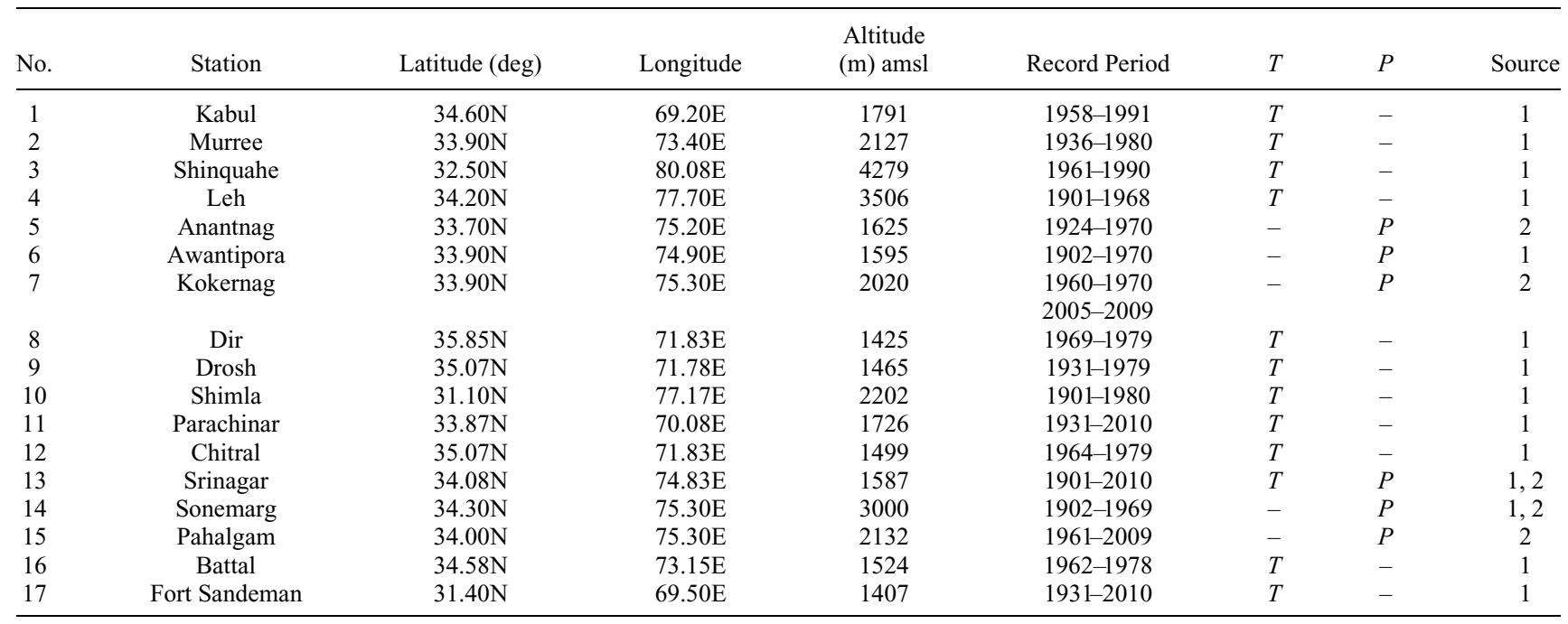


Table 5. Monthly Temperature Lapse Rates and Precipitation Gradients

\begin{tabular}{lcc}
\hline Month & $\begin{array}{c}\text { Temperature } \\
\left({ }^{\circ} \mathrm{C} \mathrm{km}^{-1}\right)\end{array}$ & $\begin{array}{c}\text { Precipitation } \\
\left(\mathrm{mm} \mathrm{km}^{-1}\right)\end{array}$ \\
\hline First halfyear & & \\
Jan & -5.90 & +119 \\
Feb & -5.50 & +110 \\
Mar & -5.70 & +122 \\
Apr & -6.0 & +87 \\
May & -6.3 & +52 \\
Jun & -6.0 & +26 \\
& & \\
Second half year & & +44 \\
Jul & -4.8 & +44 \\
Aug & -4.8 & +44 \\
Sept & -5.1 & +21 \\
Oct & -6.1 & +14 \\
Nov & -5.9 & +56 \\
Dec & -5.9 & \\
\hline
\end{tabular}

on a number of factors including the ambient temperature, precipitation, and catchment response. The runoff is high when the ambient temperature and rainfall are high (temperature controls snow and/or ice melting and precipitation as snow or rain) suggesting the stream runoff is controlled by seasons. The runoff is high in late spring and summer and very low in winter. For purposes of this study all available streamflow estimates were averaged for each month and compared to predicted streamflows using the lapse rate adjusted temperature and precipitation data, and model parameter settings as specified in Table 2. To find out whether these monthly average runoff estimates are reasonable, the daily runoff data of Jhelum River at Baramulla gauge, which receives water from the Jhelum basin (Indian controlled) with about 26 watersheds including Liddar watershed, were used for comparison. Average monthly runoff (monthly average) calculated from daily runoff and the estimated monthly average (monthly average*) calculated for a few days of runoff (these days were chosen from the Batakote gauge when the data was available) of River Jhelum at Baramula gauge showed a very good positive correlation $\left(r^{2}=0.98\right)$ (Figures 4 and 5), excluding the months with just one or two available daily data (April and May 1991, March 1992, November 1993, September 1997, August-October 1998). Therefore we estimate a $\pm 2 \%$ error in our monthly observation data as used for validation in this study.

[20] Simulated streamflow correlates reasonably well with observed flows (Figure 2), with a Pearson correlation coefficient of 0.86 and the RMSE equal to $0.05 \mathrm{~km}^{3} /$ month. Our model generally captures the magnitude and the timing of the discharge peaks in spite of its simplicity and issues with the observed data. The model captures most of the runoff characteristics and streamflow in the Liddar watershed and by extension has the potential to be effectively used in other snow dominated mountainous catchments.

[21] Observations of 10 years of streamflow and precipitation data (1991 to 2000) reflects the consistent and dominant contribution from snowmelt and icemelt during spring and summer seasons (Figure 3a). The catchment receives $\sim 50 \%$ of its annual discharge in 3 months (May to July) and $77 \%$ of its annual discharge in 6 months (April to September). This melt season strongly coincides with peak water demand in summer, runoff water is primarily used to supply irrigation water to agriculture. It is important to note that most of the area becomes snow free by July except the E-W oriented deep valleys at higher elevations $(>3000 \mathrm{~m}$ ) which along with the rainfall and glacier melt maintain the flow in August, September, and October. The contribution of the glacier melt to runoff is negligible, even in summer, as illustrated in Figure $6 \mathrm{~b}$ which shows a very small runoff stream in August $\left(\sim 15 \mathrm{~L} \mathrm{~s}^{-1}\right)$ from the largest glacier (Kolahoi) in the watershed.

\section{Results and Discussion}

\subsection{Trends 1901-2010}

\subsubsection{Observed Precipitation and Temperature}

[22] Temperature and precipitation records available from weather stations across the Indus basin indicate an overall increase of regional temperature and precipitation. Data from the long-term Srinagar weather station, used as the primary weather data source in this study, shows a warming of about $0.9^{\circ} \mathrm{C}\left(0.008^{\circ} \mathrm{C} \mathrm{yr}^{-1}\right)$ during the $1901-$ 2010 period, with temporal trends similar to those observed for the northern hemisphere average patterns reported in the literature [IPCC, 2007]. Annual precipitation increases slightly over the period of record by about $<3 \%(0.026$ $\left.\mathrm{mm} \mathrm{yr}^{-1}\right)$. However, there is a significant variation in short term trends over the entire time period. Temperatures increased by about $0.02^{\circ} \mathrm{C} \mathrm{yr}^{-1}$ from 1901 to 1946 followed by almost negligible increase $\left(0.0004^{\circ} \mathrm{C} \mathrm{yr}^{-1}\right)$ from 1947 to 1969. From 1970 to 1990 there was a cooling trend of about $-0.02^{\circ} \mathrm{C} \mathrm{yr}^{-1}$ followed by the time period from 1991 to 2010 with the highest increasing trend $\left(0.07^{\circ} \mathrm{C} \mathrm{yr}^{-1}\right)$. Similarly an increase in precipitation by about $11 \mathrm{~mm} \mathrm{yr}^{-1}$ was observed from 1910 to 1930 followed by a diminishing trend of $2.6 \mathrm{~mm} \mathrm{yr}^{-1}$ from 1931 to 1956 . The time period from 1958 to 2010 witnessed a decreasing trend of $-2.1 \mathrm{~mm} \mathrm{yr}^{-1}$. The average seasonal temperatures (Figure 4) show little warming in summer $\left(0.001^{\circ} \mathrm{C} \mathrm{yr}^{-1}\right)$ and strong warming in winter $\left(0.02^{\circ} \mathrm{C} \mathrm{yr}^{-1}\right)$. Seasonally precipitation rates increase in spring $\left(0.19 \mathrm{~mm} \mathrm{yr}^{-1}\right)$, summer $\left(0.13 \mathrm{~mm} \mathrm{yr}^{-1}\right)$, and

Table 6. Statistics of Simulated Runoff With Every Variable Changed Independently by $\pm 5 \%$

\begin{tabular}{|c|c|c|c|c|c|c|c|c|c|c|c|c|c|c|}
\hline \multirow[b]{2}{*}{ Statistics } & \multicolumn{2}{|c|}{ WHC } & \multicolumn{2}{|c|}{ Water Loss } & \multicolumn{2}{|c|}{ Lag } & \multicolumn{2}{|c|}{ Overland Flow } & \multicolumn{2}{|c|}{ Lapse Rate } & \multicolumn{2}{|c|}{$\begin{array}{c}\text { Precipitation } \\
\text { Gradient }\end{array}$} & \multicolumn{2}{|c|}{ Snow Lag } \\
\hline & $+5 \%$ & $-5 \%$ & $+5 \%$ & $-5 \%$ & $+5 \%$ & $-5 \%$ & $+5 \%$ & $-5 \%$ & $+5 \%$ & $-5 \%$ & $+5 \%$ & $-5 \%$ & $+5 \%$ & $-5 \%$ \\
\hline Average & 1.532 & 1.533 & 1.521 & 1.541 & 1.584 & 1.493 & 1.532 & 1.532 & 1.533 & 1.531 & 1.593 & 1.472 & 1.532 & 1.532 \\
\hline Min & 0.855 & 0.862 & 0.852 & 0.865 & 0.916 & 0.815 & 0.859 & 0.859 & 0.893 & 0.802 & 0.895 & 0.822 & 0.860 & 0.858 \\
\hline Max & 1.826 & 1.827 & 1.812 & 1.838 & 1.883 & 1.783 & 1.826 & 1.827 & 1.808 & 1.812 & 1.885 & 1.768 & 1.826 & 1.826 \\
\hline SD & 0.116 & 0.116 & 0.115 & 0.117 & 0.118 & 0.114 & 0.116 & 0.116 & 0.112 & 0.118 & 0.117 & 0.115 & 0.116 & 0.116 \\
\hline
\end{tabular}




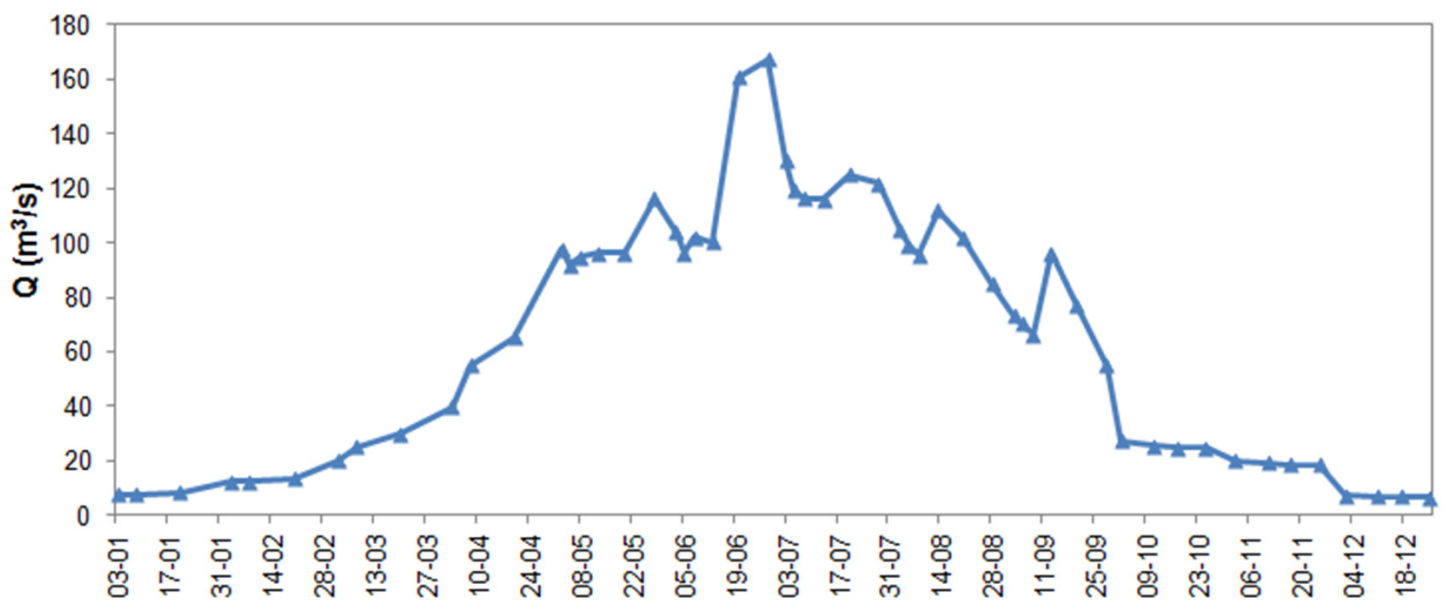

Figure 3. Daily variation of runoff (RO) of Liddar at Batakote.

autumn $\left(0.08 \mathrm{~mm} \mathrm{yr}^{-1}\right)$, while winter precipitation showed a decreasing trend $\left(-0.15 \mathrm{~mm} \mathrm{yr}^{-1}\right)$. The highest variability was found in the spring precipitation particularly in the second half of the century.

\subsubsection{Runoff, Snowmelt, and Icemelt}

[23] The monthly and annual contributions of snowmelt and glacier melt to total runoff was simulated for the duration of the observed record (1901-2010) (Figure 7). To evaluate potential changes in runoff regimes we separated our results into two equal time periods. Over the entire time period mean runoff was estimated at $1.53 \mathrm{~km}^{3} \mathrm{yr}^{-1}$, with a standard deviation of $0.12 \mathrm{~km}^{3} \mathrm{yr}^{-1}$. During the first period (1900-1955) average runoff was $1.516 \mathrm{~km}^{3} \mathrm{yr}^{-1}$ with a slightly decreasing trend; variability was relatively low with a standard deviation of $0.10 \mathrm{~km}^{3} \mathrm{yr}^{-1}$. The second period (1956-2010) experienced a higher average runoff rate $\left(1.548 \mathrm{~km}^{3} \mathrm{yr}^{-1}\right)$ with an increasing trend and greater variability (standard deviation of $0.13 \mathrm{~km}^{3} \mathrm{yr}^{-1}$ ). Over the entire study period this resulted in a slight increase in overall runoff rates (mostly in the last two decades) with an accompanying increase in runoff variability.

[24] Simulated snowmelt, although highly variable on an annual basis, showed an overall decreasing trend from 1901 to 2010. The average contribution of snowmelt to the annual runoff of the Liddar River at Batakote is estimated to be about $0.93 \mathrm{~km}^{3} \mathrm{yr}^{-1}$ (60\% of the total runoff; standard deviation of 0.09 and 0.1 for periods 1 and 2, respectively). Icemelt was estimated to contribute about $2.3 \%$ $\left(0.036 \mathrm{~km}^{3} \mathrm{yr}^{-1}\right)$ of the total runoff annually over the entire length of record $(2.5 \%$ in period 1 and $2.2 \%$ in period 2$)$. The contribution of icemelt to total runoff is highest in August $\left(0.017 \mathrm{~km}^{3}\right)$ and negligible in winter and early spring seasons.

[25] The average monthly runoff, snowmelt, and icemelt estimated for the first and second half of the reference period (Figure 8) shows maximum runoff values in July, maximum snowmelt in June and maximum icemelt in August and September. The monthly contribution from snowmelt

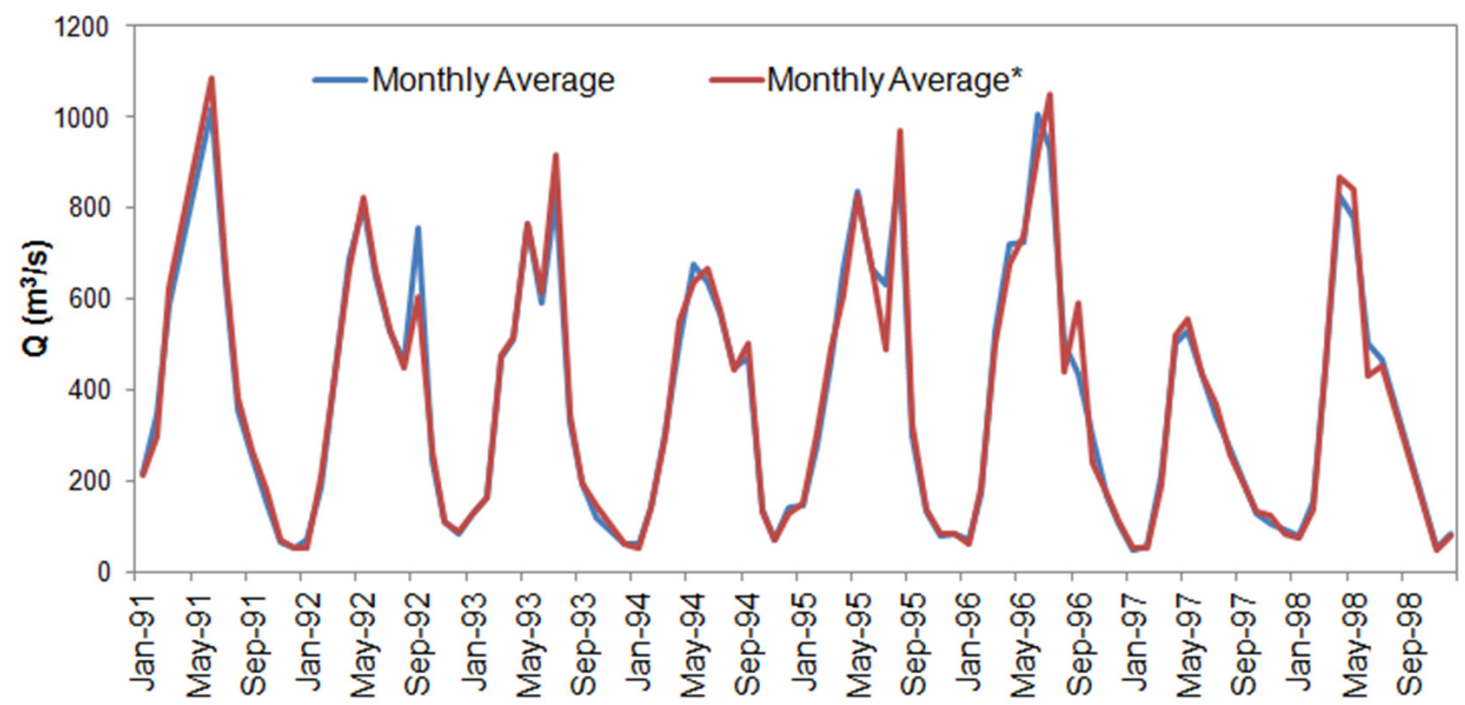

Figure 4. Average monthly runoff (monthly average) calculated from daily runoff and the estimated monthly average (monthly average*) calculated for a few days of runoff of River Jhelum at Baramula gauge. 




Figure 5. Observed and modeled monthly streamflow for upper Jhelum at Batakote, Pahalgam from 1991 to 2000 .

to runoff (river discharge) decreases steadily from $93 \%$ in June to $11 \%$ in September. An increase in runoff and snowmelt earlier in the spring season (February to April) is observed in the second half of the reference period (Figure 8), any potential decrease in peak runoff appear to be offset by increase in observed precipitation during this period. An increase in icemelt earlier (in June and July) is also noted in the second half of the reference period (Figure 8).

\subsubsection{Equilibrium Line Altitude}

[26] The equilibrium line altitude (ELA) estimated for different parts of the Himalayas is about 5000-5400 m asl in eastern Himalayas [Alford and Armstrong, 2010], 5100 $\mathrm{m}$ asl in the Indus [Immerzeel et al., 2009], 5000 [Singh and Jain, 2002] and $~ 5150 \mathrm{~m}$ asl [Bolch et al., 2012] in the western Himalayas [Singh and Jain, 2002], and $4500 \mathrm{~m}$ in the Kashmir Himalayas [Kaul, 1990]. The average ELA (30 years period) of the upper Liddar watershed was estimated using the balance between snow storage and melting at different elevations. The average ELA was found to vary from 4575 (1901-1930); 4720 (1931-1960); 4700 (1961-1990), and $4800 \mathrm{~m}$ (1991-2010) which is in good agreement with the ELA of Kashmir Himalayas and western Himalayas.

\subsection{Projected Trends During 21st Century}

\subsubsection{Projected Changes for Temperature and} Precipitation

[27] The mean monthly temperature and precipitation simulated over the upper Liddar watershed for the present and future climate (Figure 9) suggest the overall warming and more precipitation under all climate change scenarios. The increase of temperature is observed in all the seasons with a rise of up to $69 \%, 55 \%, 54 \%$, and $34 \%$ in autumn, spring, winter, and summer seasons, respectively, in the second half of the 21 st century. The increase of precipitation is observed in all seasons under all climate change scenarios with the exception of autumn which showed decrease in precipitation under $25 \%$ climate change scenario. The rise in precipitation was high in winter up to $21 \%$ and less in summer up to $9 \%$ by the end of the 21 st century. The results suggest more warming and more precipitation in the second half of the century.

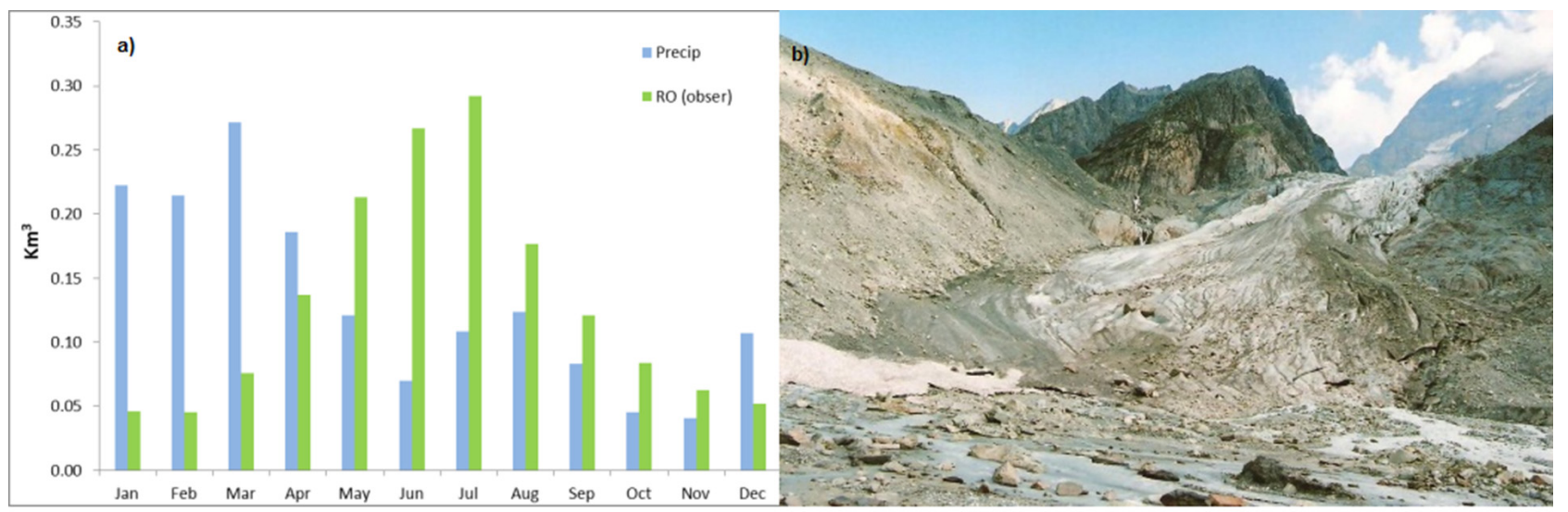

Figure 6. (a) Relationship between measured average monthly stream discharge at Batakote, and precipitation; (b) the discharge of Kolahoi Glacier in August (picture by first author). 


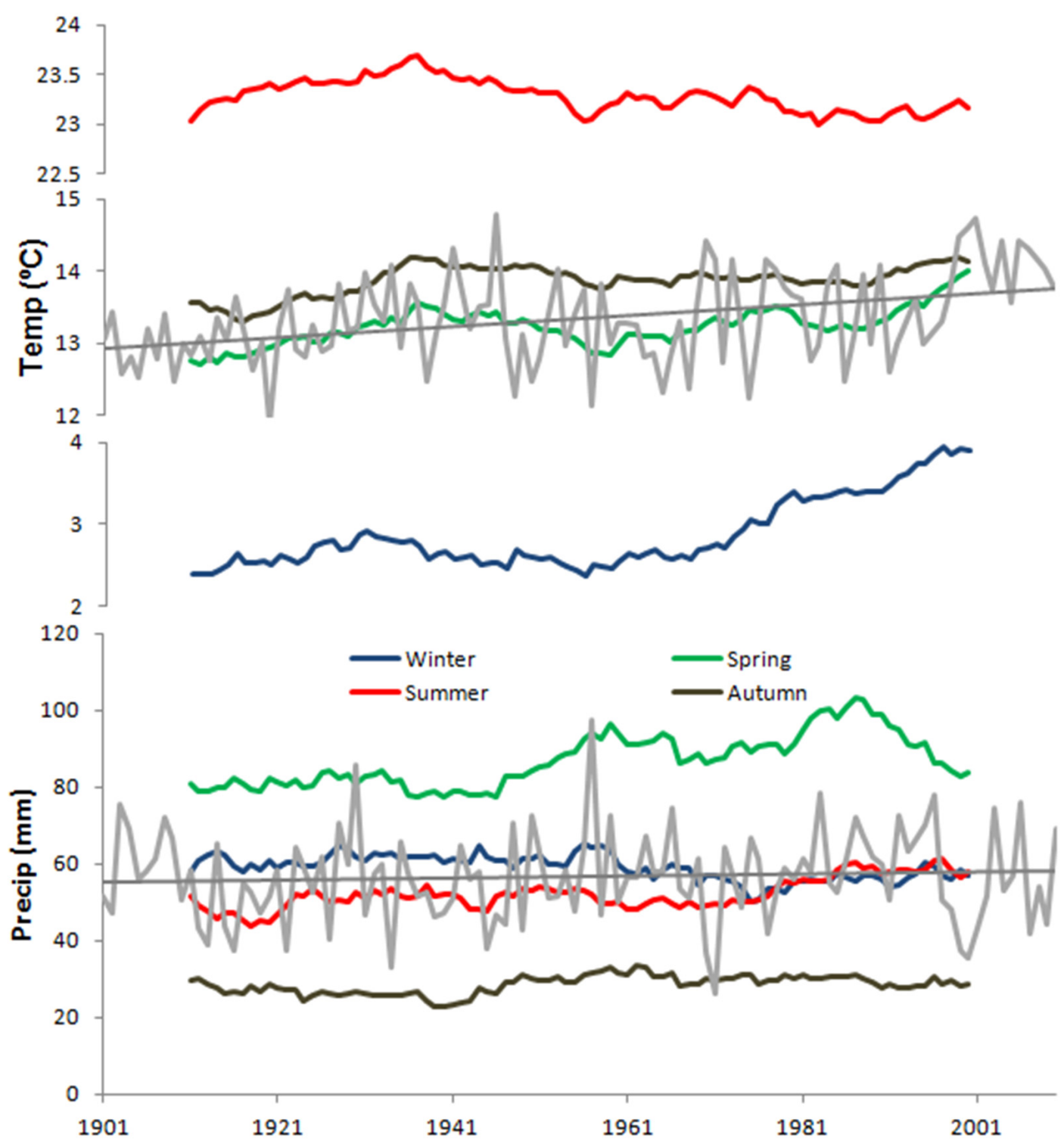

Figure 7. Annual averages (gray) and 20 year moving seasonal averages of temperature and precipitation; winter (December to February), spring (March to May), summer (June to August), and autumn (September to November).

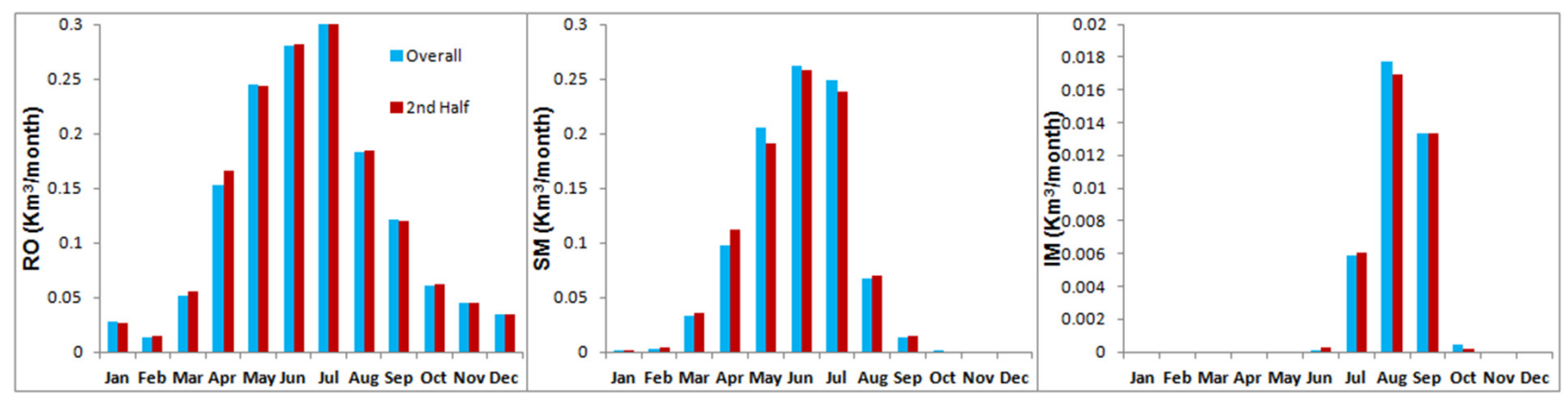

Figure 8. Average monthly runoff (RO), snowmelt (SM) and icemelt (IM; note change in scale) estimated for the first and second half of the reference period (1901-2010). 



Figure 9. Mean annual cycle of temperature and precipitation over the watershed simulated for present climate (1901 to 2010: average of first half and second half) and future climate (2001 to 2110 : average of first half and second half) under different climate change scenario.

\subsubsection{Projected Changes for Runoff, Snowmelt, and} Icemelt

[28] The yearly and monthly simulated runoff, snowmelt, and icemelt for the 21 st century under $25 \%, 50 \%$, and $75 \%$ climate change scenarios are presented in Figures 10 and 11. Results suggest that the average annual runoff of the Liddar watershed increases up to $6 \%$ and $12 \%$ in the first and second half of the 21 st century, respectively. Runoff shows a significant decrease in summer and increase in spring. The timing of peak runoff changes from July to May in the first half century and to April in the second half of the 21st century (Figure 11).

[29] The contribution from snowmelt to total annual runoff, however, decreases under the climate change scenarios with reductions of about $6 \%$ and $13 \%$ in the first and second half of the 21 st century, respectively. Large changes in snowmelt are projected in spring, with some spring months showing a near doubling in snowmelt, hence shifting the peak runoff. Similarly runoff is greatly reduced in late summer. There is less observed change in fall runoff because increased future melt due to warming temperatures is offset by reduced snowpack availability later in the melt season. In general, the snowmelt peak reduces significantly and shifts from June/July to April/May in the second half of the century (Figure 10). The annual average icemelt contribution increases under climate change scenarios from current annual average of $0.036(2 \%)$ up to $0.065 \mathrm{~km}^{3} \mathrm{yr}^{-1}$ (4\%). The peak icemelt in August under climate change
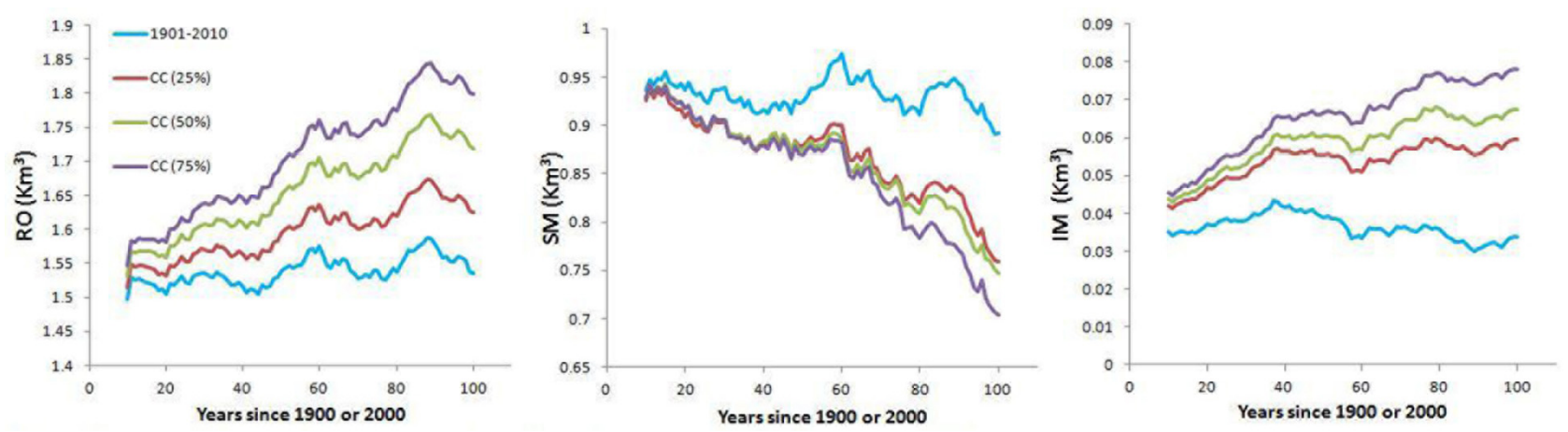

Figure 10. 20 year moving average of runoff, snowmelt, and icemelt in current (1901-2010) and future (2001-2110) climate. 


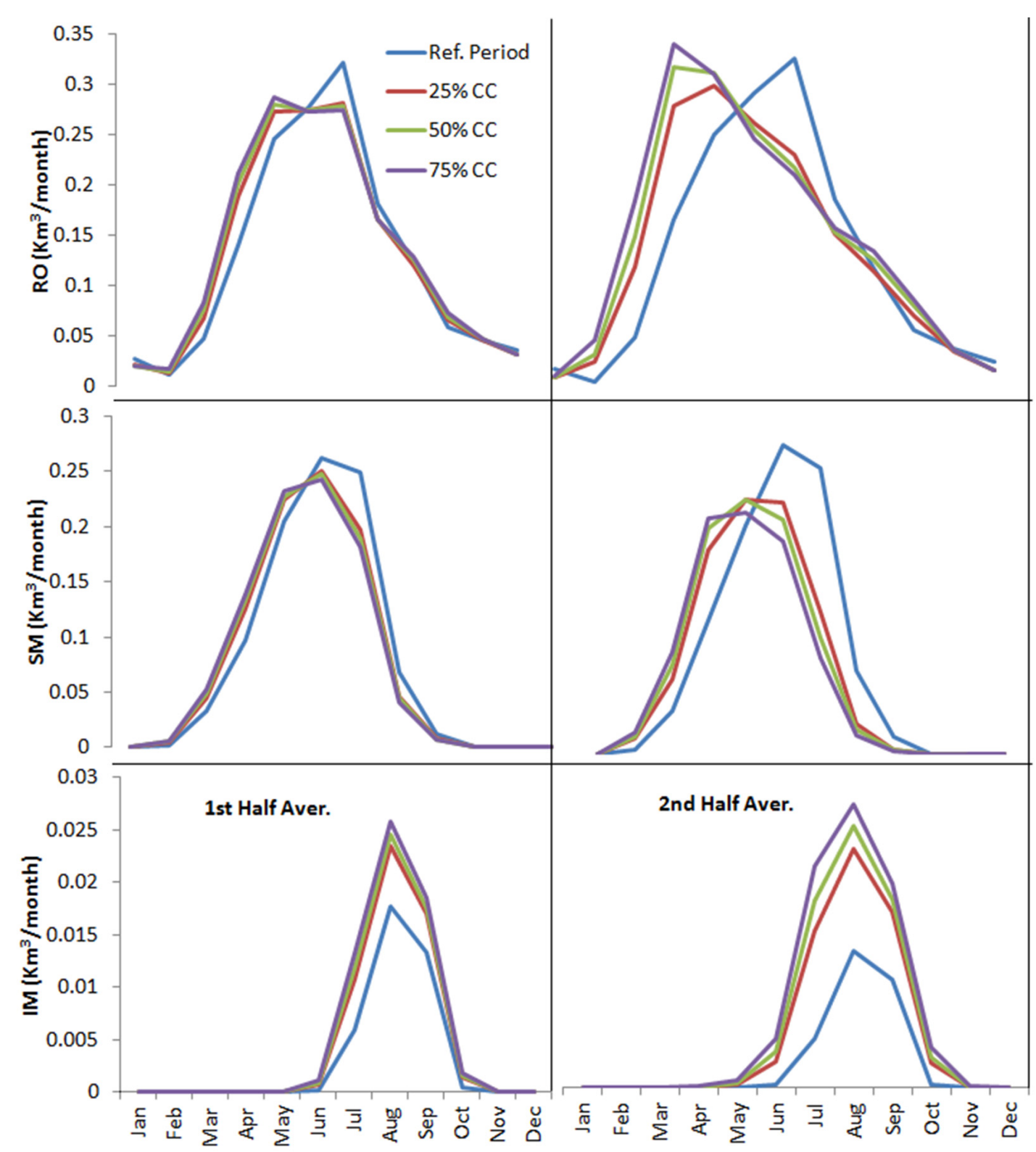

Figure 11. Plot showing the shift of runoff, snowmelt, and icemelt peaks in present (1901-2010) and future climate (under $25 \%, 50 \%$, and $75 \%$ climate change scenarios). First half average and second half average means the average values from the first half and second half of the reference period and future climate change period.

scenarios also increases from 0.017 to $0.031 \mathrm{~km}^{3}$. By late century glaciers will begin to melt much earlier in the year, likely changing glacier dynamics substantially and generally reducing ice area available for melt.

\subsubsection{Equilibrium Line Altitude}

[30] Under the applied climate change scenario the ELA shifts from $4800 \mathrm{~m}$ elevation (2001-2030) to $5089 \mathrm{~m}$ elevation (2031-2060) and about $5200 \mathrm{~m}$ elevation (2061-2090). These results suggest that by the end of the century the major glaciers of the region (Kolahoi and Sheshram glaciers) would shrink significantly and the small glaciers would disappear as the ELA would be situated above $5200 \mathrm{~m}$ elevation in the catchment. This corroborates with our modeled icemelt simulations which showed an increase in icemelt in the second half of the 21 st century under all climate change scenarios. Applying the current rate of retreat the glacierized area may be reduced to $30 \%$ to $50 \%$ by the end of the $21 \mathrm{st}$ century. This is a very conservative estimate given that smaller glaciers retreat faster than large ones and we have applied the rate of retreat of the only one major glacier (Kolahoi) to all the glaciers.

\subsection{Impact of Climate Change on Agriculture}

[31] Agriculture production in the study region is highly dependent on irrigation, especially during the growing season from summer into fall. While many studies consider the impact of climate change on agriculture by evaluating potential changes in local rainfall scenarios, in this location 
a different approach is needed, and water need should be compared to water supply for irrigation. By comparing crop water need in agricultural areas to the quantity and timing of runoff it is possible to identify some potential water resources issues in the future. To check the validity of this approach we will evaluate the historical record and compare to recognized drought events.

[32] Figure 12a shows results comparing water demand for agriculture (need) and runoff (supply) of the Liddar catchment (a representative catchment which contributes about $25 \%$ of annual flow of River Jhelum) from 1901 to 2010, with the difference variable (difference between demand and runoff) representing the amount of excess (difference variable $>0$ ) or dearth (difference variable $<1$ ) of water in the stream once theoretical water need has been met. Given the inefficiency of the existing flood irrigation systems, any time difference is less than $0.2 \mathrm{~km}^{3}$, the system would be under significant stress (assuming 50\% efficiency), and difference values below 0 indicate that there is insufficient water supply to meet demand even at $100 \%$ efficiency. Based on these results 1935, 1947, 1972, 2000, and 2001 stand out as critical years for agriculture in the historical record. Although historical data about the drought in this part of Himalaya is not available, the last decade has witnessed several moderate to severe drought years. This has forced the farmers to change the crop pattern from agricultural to horticulture.

[33] In comparison a more typically used average standard precipitation index (SPI) [McKee et al., 1993; Gutman, 1999] would not be nearly as effective at identifying these critical years since it is based primarily on precipitation anomalies and ignores the water contributions from other portions of the watershed (Figure 12b).

[34] Performing the same simulation with future climate projections of runoff and evapotranspiration (Figure 12c) shows that with the IPCC climate projections the frequency of drought events as defined by a lack of water supply for irrigation will increase steadily through the next century, and that by the end of the century typical difference values will fall below the $0.2 \mathrm{~km}^{3}$ threshold, and that it will not be unusual to have runoff based water supply fall below irrigation needs. Thus, by the end of the 21 st century, runoff

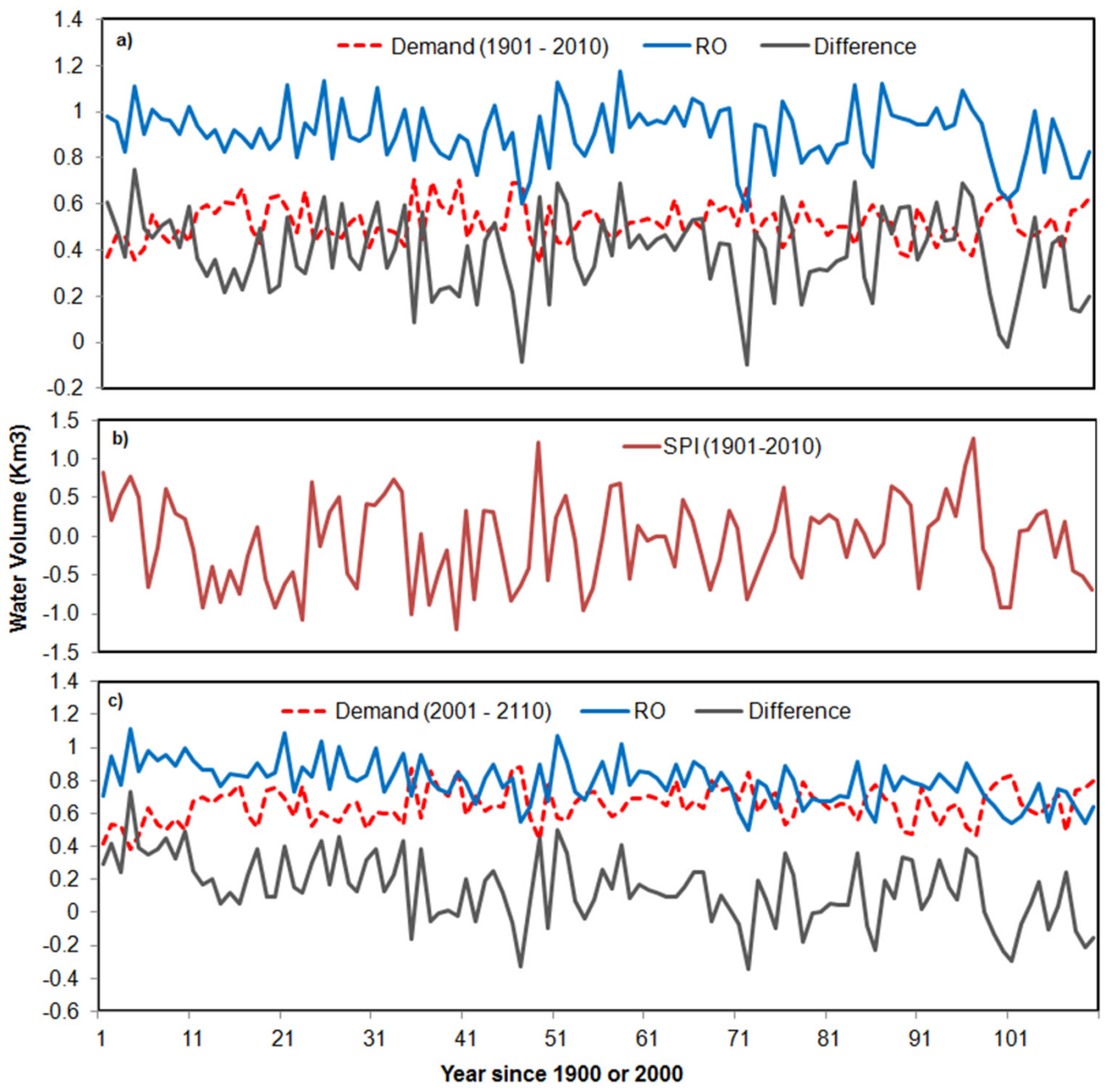

Figure 12. (a) Growing season runoff (June-Sep) compared to agricultural water demand (June-Sep), and the difference between supply and demand in the Kashmir Valley during the 20th century. (b) Growing season average standard precipitation index over the same time period and (c) future projections of water demand, supply, and the difference between supply and demand. 
would reduce water supply levels (from runoff) to below those observed during the most severe drought periods observed during the 20th century over the critical growing season period (presumably following much greater floods earlier in the year). By contrast, an analysis of SPI in the climate change scenario is not expected to change very much because warm temperatures are offset by more summer precipitation (not shown) and would not draw the same conclusions.

[35] While summer water supplies are projected to decrease in the agricultural area, total runoff for the year is expected to increase based on the same simulations. The expected changes into the future are expected to continue the trend of the last century, with declines in summer, but increased runoff earlier in the year. A comparison of simulated historical and future spring runoff conditions (MarchMay) shows spring runoff will increase by nearly $75 \%$ by the end of the 21 st century compared to current conditions (Figure 13); potentially leading to dramatic increases in spring flooding events.

\subsection{Discussion}

[36] Long term (1901-2010) temperature and precipitation records indicate an overall warming and increase in annual precipitation over the 20th century in Srinagar and Liddar watershed region. The warming trend is greater in winter compared to summer, and a decreasing trend of precipitation in winter with increased spring precipitation. The overall increase in temperature and precipitation with a differential seasonal bearing has modified the water cycle and availability of seasonal water resources from river runoff. The amplitude of the annual runoff does not show significant change, but the average annual runoff in the second half of the century is simulated to be greater compared to simulated runoff earlier in the first half of the century. The simulations attribute this trend to an increase in precipitation over the century. However, because of increasing temperatures less of this precipitation falls as snow resulting in reduced snow cover and a decreasing trend in snowmelt. Consequences of this change in precipitation timing and type is that snowmelt occurs earlier in spring leading to increased spring runoff while at the same time reducing water storage in the snowpack and reducing runoff in summer. This trend is most evident in a change in the observed runoff peak from July to June. The simulations also suggest that it is the snowmelt, not glacier melt, which is the dominant factor controlling the river hydrology. In most months (winter through spring) glacier melt makes no contribution to river runoff, and at its peak icemelt contributes on average about $0.017 \mathrm{~km}^{3}(9 \%)$ to river runoff in August. On an annual basis icemelt is simulated to contribute only $2 \%$ to total runoff. The warming climate and lower winter precipitation has also shifted the equilibrium line altitude from $\sim 4575 \mathrm{~m}$ amsl at the beginning of the 20th century to $\sim 4800 \mathrm{~m}$ amsl at the end of 20th century. One of the great benefits of this analysis is that it provides a much clearer methodology for analysis of long term trends in ice/snow/runoff conditions compared to most satellite based observational studies of climate impacts on glaciers in the Himalaya.

[37] The increase in temperature and precipitation under the climate change scenario are projected to lead to more annual runoff with a significant seasonal shift continuing the observed trend in the 20th century. Future runoff is projected to decrease sharply in summer and increase in the spring season. Runoff peaks shifts to May in the first half and to April in the second half of the 21 st century, and overall snowmelt is reduced because less precipitation falls as snow. Icemelt is projected to increase and start melting earlier in the season. Regardless of the scenario, glacial melt contributes a very small fraction to the total annual runoff in the region; $2 \%$ at the beginning of the 20th century and $4 \%$ at the end of the 21 st century. However, shifts in the equilibrium line suggest by the end of the 21 st century all the glaciers of the watershed would shrink significantly and the other small glaciers would disappear very soon. Hence this work suggests that the glaciers in the region will only have a relatively small role to play in future water resource constraints. The watershed will likely change from a glacier and snow dominated runoff regime to a nival-pluvial regime with much higher year to year variability and hence, also a higher risk of drought. In addition, uncertainties of the future precipitation have also a strong influence of the uncertainty of the future runoff. However, in catchments with larger glaciers, the icemelt contribution would increase significantly in summer months.

[38] The increase in spring runoff is a matter of concern as flooding risks are likely to increase during any moderate storm. Also the increased temperatures in July and August would increase the soil deficit and evaporation of the stored

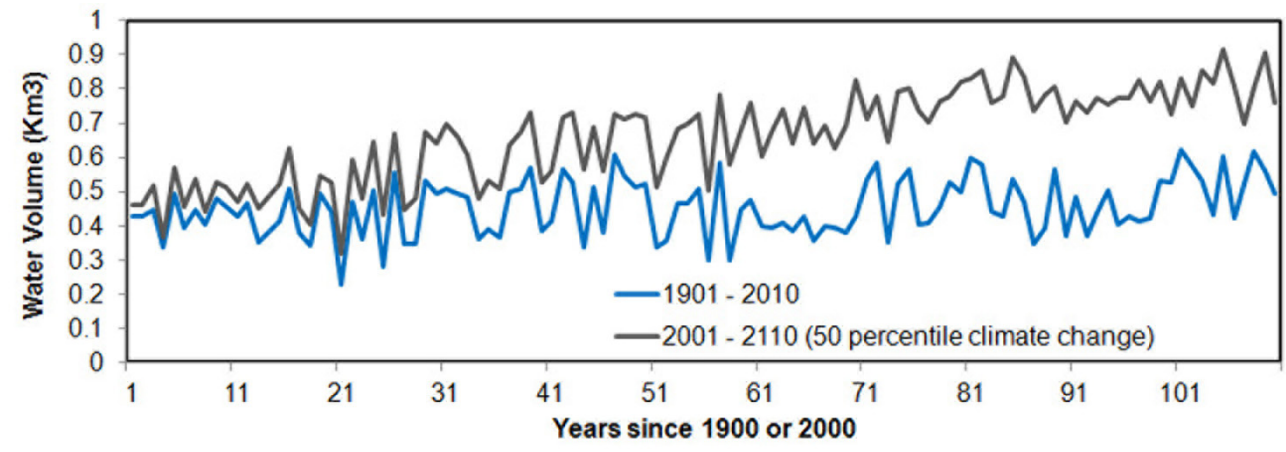

Figure 13. Historical spring runoff simulations (total runoff for MAM) and future projections of spring runoff using the same methodology with climate change projections applied to temperature and precipitation input data. 
water and ultimately reduce the water supply for irrigation agriculture in the summer season. Under current climate conditions deficits during the summer growing season are typically offset by water supplies from snowmelt. The redistribution of the water resources due to the seasonal shift of streamflow and decreased runoff in summer (growing season) is likely to lead to more agricultural stress because water resources will decline during the period of greatest need in summer. By the end of the 21 st century the water for irrigation needs in the Kashmir Valley are projected to be insufficient to meet typical demand. Our projections suggest that these impacts will manifest themselves by mid-century. These changes have the potential to affect the economy and food security of the region which is dependent on the availability of water resources during the growing season. Altering crop cycles to earlier in the spring may not be feasible due to the freezing/lower temperatures during that period. At the same time altering large scale infrastructure to create more water storage facilities is also an economic burden and will require a better integrated water management across all the large watersheds of the region.

\section{Conclusions}

[39] The water budget model presented in this paper is very important for hydrologists and planners working in the Himalayan region with sparse availability of climate data. Second, this methodology allows for analysis of long term climate/hydrology trends within watersheds of the region putting into perspective many of the short term satellite based estimates of hydrological change in the region (see Table 1). Long term (more than a century) temperature and precipitation data were used to simulate various components of river flow including snowmelt and icemelt. Snowmelt was found to be the dominant component of the Liddar River contributing about $60 \%$ to the total annual flow, with lesser contribution from glacier melt $(2 \%)$. Our study suggests that when discussing the future of water resources in the region, the issue of glacier contributions to future hydrologic change needs to be treated with much greater care than has been the case in the literature. Glaciers contribute very little to overall runoff in this watershed, and this is likely the case in other watersheds also. Hence projections based on loss of glaciers should be reconsidered. The period since 1990 is already showing a shift toward earlier runoff peaks from these watersheds and this trend is likely to continue based on the IPCC A1B climate scenario simulations. While the future projections suggest warmer conditions with more precipitation, the greater changes to runoff regimes of the upper Himalayas will be due to changes in the snow accumulation and melt. Practically, the projected shift to large increases runoff in spring could lead to flooding hazards during this season. At the same time the loss of snow pack in spring is projected to lead to large decreases in summer runoff which is very likely to interfere with irrigation water supplies critical to present day agricultural practices in the region.

[40] The watershed will likely change from a glacier and snow dominated runoff regime to a nival-pluvial regime with much higher year to year variability and hence, also a higher risk of drought. In addition, uncertainties of the future precipitation have also a strong influence of the uncertainty of the future runoff.
[41] Acknowledgments. The first author is thankful to United States India Educational Foundation (USIEF), New Delhi for the support to carry out this work as part of Fulbright-Nehru Senior Research Fellowship and to the Department of Geography, the University of Kansas, KS for providing space and all the existing facilities. Code used for this project evolved from code developed in National Science Foundation EPSCoR grant KAN0061396/KAN006263 and NSF grant BCS-0751715. The authors are highly indebted to anonymous reviewers whose comments and suggestions have significantly improved the quality of the manuscript.

\section{References}

Akhtar, M., N. Ahmad, and M. J. Booij (2008), The impact of climate change on the water resources of Hindukush-Karakuram-Himalaya region under different glacier coverage scenarios, J. Hydrol., 355, 148163.

Alford, D., and R. Armstrong (2010), Role of glaciers in stream flow from the Nepal Himalaya, Cryosphere Discuss., 4, 469-494.

Archer, D. R., and H. J. Fowler (2004), Spatial and temporal variations in precipitation in the upper Indus Basin, global teleconnections and hydrological implications, Hydrol. Earth Syst. Sci., 8, 47-61.

Archer, D. R., N. Forsythe, H. J. Fowler, and S. M. Shah (2010), Sustainability of water resources management in the Indus Basin under changing climatic conditions, Hydrol. Earth Syst. Sci., 14, 1669-1680.

Barnett, T. P., J. C. Adam, and D. P. Lettenmaier (2005), Potential impacts of a warming climate on water availability in snow-dominated regions, Nature, 438, 303-309, doi:10.1038/nature04141.

Berthier, E., Y. Arnaud, R. Kumar, S. Ahmad, P. Wagnon, and P. Chevallier (2007), Remote sensing estimates of glacier mass balances in the Himachal Pradesh (Western Himalya, India), Remote Sens. Environ., 108, 327 338.

Bolch, T., et al. (2012), The state and fate of Himalayan glaciers, Science, 336(6079), 310-314.

Bookhagen, B., and D. W. Burbank (2010), Toward a complete Himalayan hydrological budget: Spatiotemporal distribution of snowmelt and rainfall and their impact on river discharge, J. Geophys. Res., 115, F03019, doi: 10.1029/2009JF001426.

Briscoe, J., and U. Qamar (2007), Pakistan's Water Economy Running Dry, Oxford University Press, Karachi

Eriksson, M., X. Jianchu, A. B. Shrestha, R. A. Vaidya, S. Nepal, and K. Sandstörm (2009), The Changing Himalayas: Impact of Climate Change on Water Resources and Livelihoods in the Greater Himalayas, ICIMOD, Kathmandu.

Feddema, J. J. (1998), Estimated impacts of soil degradation on the African water balance and climate, Clim. Res., 10(2), 127-141.

Feddema, J. J. (2005), A revised Thornthwaite type global climate classification, Phys. Geog., 26(6), 442-466.

Fowler, H. J., and D. R. Archer (2006), Conflicting signals of climate change in the upper Indus Basin, J. Clim., 19, 4276-4293.

Gutman, N. B. (1999), Accepting the Standardized Precipitation Index: A calculation algorithm, J. Am. Water Resour. Assoc., 35(3), 311-322.

Hamon, W. R. (1963), Computation of direct runoff amounts from storm rainfall, Int. Assoc. Sci. Hydrol. Publ., 63, 52-62.

Hock, R. (2003), Temperature index melt modelling in mountain areas, J. Hydrol., 282, 104-115.

Immerzeel, W. W., P. Droogers, S. M. de Jong, and M. F. P. Bierkens (2009), Large-scale monitoring of snow cover and runoff simulation in Himalayan river basins using remote sensing, Remote Sens. Environ., 113, 40-49, doi:10.1016/j.rse.2008.08.010.

Immerzeel, W. W., L. P. van Beek, and M. F. Bierkens (2010), Climate change will affect the Asian water towers, Science, 328, 13821385.

IPCC (2007), Clim. Change 2007: Impacts, Adaptation and Vulnerability. Contribution of Working Group II to the Fourth Assessment Report of the Intergovernmental Panel on Clim. Change, edited by M. L. Parry, et al., 976 pp., Cambridge University Press, Cambridge.

Ives, J. D., and B. Messerli (1989), The Himalayan Dilemma: Reconciling Development and Conservation, John Wiley, London, doi:10.4324/ 9780203169193.

Jeelani, G., N. A. Bhat, and K. Shivanna (2010), Use of $\delta^{18}$ O tracer to identify stream and spring origins of a mountainous catchment: A case study from Liddar watershed, Western Himalaya, India, J. Hydrol., 393, 257264

Karim, A., and J. Veizer (2002), Water balance of the Indus River Basin and moisture source in the Karakoram and western Himalayas: Implications 
from hydrogen and oxygen isotopes in river water, J. Geophys. Res., 107(D18), 4362, doi :10.1029/2000JD000253.

Kaul, M. N. (1990), Glacial and Fluvial Geomorphology of Western Himalaya: Liddar Valley, 327 pp., Concept, New Delhi.

Lu, J., G. Sun, S. G. McNulty, and D. Amatya (2005), A comparison of six potential evapotranspiration methods for regional use in the Southeastern United States, J. Am. Water Resour. Assoc., 41(3), 621-633.

Mather, J. R. (1978), The Climatic Water Budget in Environmental Analysis, 239 pp., Lexington Books, Lexington, MA.

McCabe, G. J., and D. M. Wolock (1999), Future snowpack conditions in the Western United States derived from general circulation model climate simulations, J. Am. Water Resour. Assoc., 35, 1473-1484.

McKee, T. B., N. J. Doeskin, and J. Kleist (1993), The relationship of drought frequency and duration to time scales, Proceedings of 8th conference on Applied Climatology, American Meteorological Society, Boston, pp. 179-184.

Raina A. N. (2002), Geography of Jammu and Kashmir, pp. 16-38, Radha Krishan Anand and Co., Jammu.

Rees, H. G., and D. N. Collins (2006), Regional differences in response of flow in glacier fed Himalayan rivers to climate warming, Hydrol. Processes, 20, 2157-2169.
Scherler, D., B. Bookhagen, and M. R. Strecker (2011), Spatially variable response of Himalayan glaciers to climate change affected by debris cover, Nat. Geosci., 4, 156-159.

Singh, P., and S. K. Jain (2002), Snow and glacier melt in the Satluj River at Bhakdra Dam in the western Himalayan region, Hydrol. Sci. J, 47, 93-106.

Singh, P., S. K. Jain, and N. Kumar (1997), Estimation of snow and glaciermelt contribution to the Chenab River, western Himalaya, Mount. Res. Dev., 17, 49-56.

Thornthwaite, C. W. (1948), An approach toward a rational classification of climate, Geogr. Rev., 38, 55-94.

Thornthwaite, C. W., and J. R. Mather (1955), The water balance, Publ. Climatol., 8, 1-104.

Tiwari, V. M., J. Wahr, and S. Swenson (2009), Dwindling groundwater resources in northern India, from satellite gravity observations, Geophys. Res. Lett. 36, L18401, doi:10.1029/2009GL039401.

Willmott, C. J., C. M. Rowe, and Y. Mintz (1985a), Climatology of the terrestrial seasonal water cycle, J. Climatol., 5, 589-606.

Willmott, C. J., S. G. Ackleson, R. E. Davis, J. J. Feddema, K. M. Klink, D. R. Legates, J. O'Donnell, and C. M. Rowe (1985b), Statistics for the evaluation and comparison of models, J. Geophys. Res., 90(C5), 89959005. 